\title{
Pengaruh Kualitas Jasa Dan Pelayanan Prima Terhadap Kepuasan Konsumen Pada PT. Deli Mega Valutindo
}

\author{
Eliakim Purba \\ Universitas Amir Hamzah \\ eliakim_purba@yahoo.com
}

\author{
Diding Kusnady \\ Politeknik Ganesha Medan \\ didingkusnady@polgan.ac.id
}

\begin{abstract}
ABSTRAK
Penelitian ini bertujuan untuk mengetahui seberapa besar pengaruh dari Kualitas Jasa dan Pelayanan Prima terhadap Kepuasan Konsumen pada PT. Deli Mega Valutindo. Metodologi penelitian yang digunakan adalah metode deskriptif kuantitatif, unit analisis dalam penelitian ini adalah PT. Deli Mega Valutindo serta unit observasinya adalah pelanggan pada PT. Deli Mega Valutindo. Populasi dalam penelitian ini adalah pelanggan pada PT. Deli Mega Valutindo sebanyak 354 perusahaan. Teknik penentuan jumlah sampel yang digunakan dalam penelitian ini adalah rumus slovin dan berjumlah sebanyak 78 responden. Metode penelitian yang digunakan yakni dengan teknik pengumpulan data melalui penelitian kepustakaan dan penelitian lapangan yang dilakukan secara sistematik berdasarkan tujuan penelitian. Metode analisis yang digunakan untuk memecahkan permasalahan dan membuktikan hipotesis adalah dengan analisis deskriptif, analisis regresi. Analisis ini mencakup: validitas dan realiabilitas, uji asumsi klasik, analisis regresi berganda, pengujian hipotesis melalui uji t dan F, dan uji koefisien determinasi $\left(\mathrm{R}^{2}\right)$. Dari analisis tersebut diperoleh analisis regresi $Y=\mathbf{1 , 2 0 8}+\mathbf{0 , 2 1 0 X} \mathbf{1}+\mathbf{0 , 4 0 8} \mathrm{X}_{2}+\mathbf{e}$ Hasil uji koefisien determinasi $\left(\mathrm{R}^{2}\right)$ menunjukkan bahwa 54,3\% variable Kepuasan Konsumen dipengaruhi oleh variable Kualitas Jasa dan Pelayanan Prima, sedangkan sisanya sebesar 45,7\% dijelaskan oleh pengaruh faktor lain atau variabel di luar model seperti pelayanan, nilai pelanggan dan lainnya yang tidak dibahas di dalam penelitian ini. Hasil uji $\mathrm{F}$ menunjukkan bahwa $F_{\text {hitung }}>F_{\text {tabelyaitu }} 44,565>3.12$ yang berarti variable bebas (Kualitas Jasa dan Pelayanan Prima) secara serempak berpengaruh terhadap variable terikat (Kepuasan Konsumen). Sedangkan uji t menunjukkan bahwa variable Kualitas Jasa berpengaruh positif dan signifikan terhadap Kepuasan Konsumen pada PT. Deli Mega Valutindo dimanat $_{\text {hitung }}$ 2,927 $>t_{\text {tabel }} 1.665$ dan variable Pelayanan Prima berpengaruh positif dan signifikan terhadap Kepuasan Konsumen pada PT. Deli Mega Valutindo dimana thitung $6,926>t_{\text {tabel }} 1.665$.
\end{abstract}

Kata Kunci : Kualitas Jasa,Pelayanan Prima, Kepuasan Konsumen. 


\section{PENDAHULUAN}

Dalam era globalisasi sekarang ini maka kondisi yang terjadi sudah jauh sekali berubah, masyarakat sudah tumbuh dalam dan berkembang dalam suasana yang begitu terbuka. Berbagai informasi bisa diperoleh dengan cepat, dan berbagai keputusan bisa dilakukan dengan mudah. Dalam dunia perbankan di Indonesia telah terjadi perubahan yang cukup menarik yaitu bergesernya Dunia bisnis sudah mengubah konsep manajemen dari konvensional ke modern. Perubahan konsep tersebut adalah sebuah tuntutan zaman, jika perusahaan tidak menerapkan maka artinya perusahaan akan ditinggalkan oleh konsumen. Segala aktivitas bisnis bisa dilakukan dengan lebih sederhana tanpa ada beban dan tekanan, permasalahan hanya satu kecepatan dalam mengambil keputusan secara baik dan akurat.

Kondisi ini tidak terkecuali pada saat transaksi bisnis mengikutkan diperganakannya valuta asing sebagai alat pembayaran. Para manajer keuangan berusaha kuat dengan menerapkan bergbagai formula mampu menempatkan dan memperkirakan kestabilan valas secara konstan dalam suatu kurun waktu akuntansi. Valuta asing adalah mata uang yang berasaldari negara lain dan dipakai sebagai perhitungan untuk melihat nilai mata uang domestik ketika dikonversikan dengan mata uang asing tersebut. Seperti mata uang dollar Amerika Serikat dikonversi dengan rupiah, Yen Jepang dengan Rupiah, dan lain sebagainya.Pasar valuta asing atau yang sering disebut dengan istilah foreign exchange market merupakan pasar dimana transaksi valuta asing dilakukan baik antar negara maupun dalam suatu negara. Transaksi dapat dilakukan oleh suatu badan/ perusahaan atau secara perseorangan dengan berbagai tujuan. Dalam setiap kali melakukan transaksi valuta asing. Dalam setiap kali melakukan transaksi valuta asing, maka digunakan kurs (nilai tukar). Nilai tukar ini dapat berubah ubah sesuai kondisi dari waktu ke waktu yang disebabkan oleh berbagai faktor seperti faktor ekonomi dan politik. Dewasa ini perhatian terhadap kepuasan konsumen atau ketidakpuasan konsumen semakin besar. Persaingan yang semakin ketat, dimana banyak produsen yang terlibat dalam pemenuhan kebutuhan dan keinginaan konsumen, menyebabkan setiap perusahaan harus menempatkan orientasi kepuasan konsumen sebagai tujuan utama dan diyakini sebagai kunci utama untuk memenangkan persaingan adalah memberikan nilai dan kepuasan kepada konsumen melalui penyampaian produk dan jasa dengan harga bersaing. Pada umumnya harapan dari konsumen merupakan perkiraan/ keyakinan konsumen tentang apa yang diterimanya bila mereka membeli atau mengkonsumsi suatu produk. Kepuasan ini mendatangkan keuntungan karena biaya mendapatkan konsumen baru lima kali lebih tinggi daripada mempertahankan yang sudah ada. Kualitas pelayanan yang diukur berdasarkan pada perbedaan antara nilai harapan dengan nilai kinerja yang dirasakan oleh konsumen.

PT. Deli Mega Valutindo adalah perusahaan yang begerak dibidang penjualan nilai tukar uang asing atau biasa disebut valas. PT. Deli Mega Valutindo menyediakan 
berbagai jenis mata uang. Sebagai perusahaan terkemuka, PT. Deli Mega Valutindo terletak di Jalan Asia No. 606 Medan. Dalam operasionalnya, PT. Deli Mega Valutindo mengalami peningkatan pembelian. Masalah pelayanan sebenarnya bukanlah hal yang sulit atau rumit, tetapi apabila hal ini kurang diperhatikan maka dapat menimbulkan hal-hal yang rawan karena sifatnya yang sangat sensitif. Sistem pelayanan perlu didukung oleh kualitas pelayanan, fasilitas yang memadai dan etika atau tata krama. Sedangkan tujuan memberikan pelayanan adalah untuk memberikan kepuasan kepada konsumen/ pelanggan, sehingga berakibat dengan dihasilkannya nilai tambah bagi perusahaan.

Kepuasan konsumen yang baik dapat menjadi keunggulan bersaing bagi perusahaan. Pelayanan prima juga merupakan kunci untuk mencapai kesuksesan. Baik tidaknya kualitas pelayanan barang atau jasa tergantung pada kemampuan produsen dalam memenuhi harapan konsumen secara konsisten. PT. Deli Mega Valutindo bisa dikatakan sebagai perusahaan yang berhasil jika layanan yang dirasakan sama atau melebihi kualitas layanan yang diharapkan, seperti sebagai karyawan maka harus memiliki tutur kata yang baik, berpenampilan yang menarik, harus benar-benar dalam melayani pelanggannya, sebagaimana tugasnya yang harus siap selalu melayani pelanggan yang memang memerlukannya. Bersikap jujur pada pelayanan agar dapat di percaya juga salah satu bentuk pelayanan primaprematur atas prosedur audit penting menjadi perhatian, khususnya bagi para auditor profesional agar fenomena penghentian ini dapat dideteksi dan dihilangkan. karena auditor tidak melakukan prosedur audit yang mencukupi dapat menyebabkan auditor Keadaan atau kondisi tekanan waktu atau Time Pressure yaitu kondisi dimana auditor mendapatkan tekanan dari Kantor Akuntan Publik (KAP) tempatnya bekerja untuk menyelesaikan audit pada waktu dan anggaran biaya yang telah ditentukan sebelumnya. Seorang auditor dalam kondisi mendapat tekanan waktu dapat melakukan tindakan penghentian prematur atas prosedur audit. Adanya praktik penghentian prematur atas prosedur audit, tentu saja sangat berpengaruh secara langsung terhadap kualitas laporan audit yang dihasilkan auditor, sebab apabila salah satu langkah dalam prosedur audit dihilangkan, maka kemungkinan auditor membuat judgment yang salah akan semakin tinggi. Kesalahan pembuatan opini atau judgment yang disebabkan dituntut secara hukum. Adanya Time Pressure karena adanya keterbatasan waktu yang diberikan oleh klien akan menyebabkan semakin tingginya penghentian prematur atas prosedur audit yang sedang dikerjakan oleh auditor.

\section{LANDASAN TEORI}

\subsection{Defenisi Operasional}

Kualitas pelayanan bisa diartikan sebagai ukuran seberapa bagus tingkat layanan yang diberikan mampu sesuai dengan ekspektasi pelanggan.

Pelayanan prima adalah melayani sebagai melayani lebih dari yang diharapkan, 
dengan memberikan perhatian kepada waktu, ketepatan, keamanan, kenyamanan, kualitas, biaya, proses, dan kepuasan. Kepuasan konsumen adalah hasil akumulasi dari konsumen atau pelanggan dalam menggunakan produk dan jasa.

\section{METODE PENELITIAN}

\subsection{Lokasi Penelitian}

Penelitian berlokasi di PT. Deli Mega Valutindo, Jalan. Ahmad Yani VII No.94, Kesawan, Medan Bar., Kota Medan, Sumatera Utara 20111, Indonesia. Nomor telepon: +62 61 4513535, kode pos: 20111 .

\subsection{Populasi dan Sampel}

Dalam penelitian ini yang menjadi populasi adalah konsumen pada PT. Deli Mega Valutindo yang melakukan jual beli produk dari bulan Januari 2018 sampai dengan Maret 2018 sebanyak 354 konsumen. Dalam penelitian ini penulis mempersempit populasi dengan menghitung ukuran sampel yang dilakukan dengan menggunakan teknik Slovin. Sehingga sampel penelitian ini sebanyak 78 responden.

Variabel dan Defenisi Operasional

Variabel Penelitian

Variabel yang akan dianalisis dalam penelitian ini terdiri atas :

a) Variabel Bebas (X1) yaitu kualitas jasa

b) Variabel Bebas (X2) yaitu pelayanan prima

c) Variabel Terikat (Y) yaitu kepuasan konsumen

\subsection{Teknik Analisis Data}

Analisi Regresi Linear Berganda

Model análisis data yang digunakan dalam penelitian kali ini adalah model análisis regresi berganda. Peneliti menggunakan regresi linear berganda karena model ini berguna untuk mencari pengaruh antara dua atau lebih variabel bebas terhadap variabel terikat yang ada. Model persamaan regresi berganda adalah : $\mathrm{Y}=\mathrm{a}+\mathrm{b} 1 \mathrm{X} 1$ + b2 X2 + e Keterangan:

$\mathrm{Y} \quad=$ Kepuasan konsumen $\mathrm{a} \quad=$ Konstanta

b1-2 = Koefisien regresi variabel independen

$\mathrm{X} 1=$ Variabel kualitas jasa X2 = Variabel pelayanan prima $\mathrm{e}$ $=$ Standard Error 


\subsection{Koefisien Determinasi (R2)}

Hasil penelitian Koefisien Determinasi (R2) digunakan untuk mengukur proporsi atau presentasi sumbangan variabel bebas yang diteliti yaitu kualitas jasa (X1) dan pelayanan prima (X2) terhadap kepuasan konsumen (Y). Koefisien determinasi berkisar antara 0 sampai dengan 1 . Hal ini apabila $\mathrm{R} 2=0$ menunjukan ketidakmampuan variabel independen dalam mempengaruhi variabel dependen. Bila R2 mendekati 1 menunjukan kemampuan variabel independen dalam mempengaruhi variabel dependen.

\subsection{Uji Hipotesis}

Untuk mengetahui signifikansi dari hipotesa dalam penelitian ini maka perlu dilakukan beberapa uji sebagai berikut :

1. Uji F

Uji F statistik menunjukkan apakah semua variabel independen atau bebas yang dimasukkan dalam model mempunyai pengaruh secara bersama-sama terhadap variabel dependen atau terikat. Jika nilai Fhitung lebih besar daripada Ftabel, maka hipotesis diterima artinya bahwa semua variabel independen secara serentak dan signifikan mempengaruhi variabel dependen. Pengujian dilakukan dengan menggunakan tingkat signifikansi sebesar $0,05(\alpha=5 \%)$.

Kriteria uji signifikansi simultan (Uji F) adalah sebagai berikut:

1. Jika nilai signifikasi $\mathrm{F}>0,05$ atau Fhitung < Ftabel, maka hipotesis ditolak. Ini berarti bahwa secara bersama-sama seluruh variabel independen tidak mempunyai pengaruh yang signifikan terhadap variabel dependen.

2. Jika nilai signifikansi $\mathrm{F} \leq 0,05$ atau Fhitung $>$ Ftabel, maka hipotesis diterima. Ini berarti bahwa secara bersama-sama seluruh variabel independen mempunyai pengaruh yang signifikan terhadap variabel dependen.

\section{Uji t}

Uji t statistik menunjukkan seberapa jauh pengaruh satu variabel penjelas atau independen secara individual dalam menerangkan variasi variabel dependen, jika nilai t statistik hitung lebih tinggi dibandingkan ttabel, maka hipotesis diterima. Hal ini menyatakan bahwa suatu variabel independen secara individual mempengaruhi variabel dependen. Pengujian dilakukan dengan menggunakan tingkat signifikansi sebesar $0,05(\alpha=5 \%)$. Kriteria uji signifikansi individual (Uji t) adalah sebagai berikut:

1. Jika nilai signifikansi $t>0,05$ maka hipotesis ditolak. Ini berarti bahwa secara parsial variabel independen tidak mempunyai pengaruh yang signifikan terhadap variabel dependen. 
2. Jika nilai signifikansi $\mathrm{t} \leq 0,05$ maka maka hipotesis diterima. Ini berarti bahwa secara parsial seluruh variabel independen mempunyai pengaruh yang signifikan terhadap variabel dependen

\section{HASIL PENELITIAN}

\subsection{Hasil Penelitian.}

Metode Persamaan Regresi Berganda Persamaan regresi berganda secara umum adalah: $\mathrm{Y}=1,208+0,210 \mathrm{X} 1+0,408 \mathrm{X} 2+\mathrm{e}$

Koefisien 0,210 menunjukkan bahwa jika variabel kualitas jasa ditingkatkan satu satuan maka dapat diikuti peningkatan variabel kepuasan konsumen sebesar $21 \%$. Koefisien 0,408 menunjukkan bahwa jika variabel pelayanan prima ditingkatkan sebesar satu satuan maka dapat diikuti oleh peningkatan variabel kepuasan konsumen sebesar 40\%. Koefisien Determinasi (R2) Nilai R Square $=0,543$ berarti hubungan antara variabel kualitas jasa dan pelayanan prima sebesar 54,3\%. Artinya hubungan yang erat antar variabel. Angka Adjusted R Square sebesar 0,543 berarti 54,3\% kepuasan konsumen dijelaskan oleh variabel kualitas jasa dan pelayanan prima. Sedangkan 45,7\% dapat dijelaskan variabel lain yang tidak diteliti dalam penelitian ini.

Pengujian Hipotesis

1. Pengujian Hipotesis Secara Simultan Menggunakan Uji F

Hasil uji signifikansi simultan dapat dilihat tabel berikut :

Berdasarkan tabel diatas nilai Fhitung adalah 44,565 > Ftabel 3,12 dengan tingkat signifikan 0,00. Sedangkan tingkat kepercayaan $(\mathrm{a}=0,05)$. Maka terdapat pengaruh yang simultan antara kualitas jasa dan pelayanan prima terhadap kepuasan konsumen.

2. Pengujian Hipotesis secara Parsial

Menggunakan Uji t Pengaruh X1 terhadap Y

Variabel kualitas jasa memiliki nilai thitung 2,927 > ttabel 1,665. Ini berarti H1 ditolak sehingga dapat disimpulkan bahwa variabel kualitas jasa berpengaruh terhadap kepuasan konsumen pada PT. Deli Mega Valutindo.

a. Pengaruh X2 terhadap Y

Variabel pelayanan prima memiliki nilai thitung 6,926 > ttabel 1,665. Ini berarti H1 ditolak sehingga dapat disimpulkan bahwa variabel kualitas jasa berpengaruh terhadap kepuasan konsumen pada PT. Deli Mega Valutindo. 


\subsection{Pembahasan Hasil Penelitian}

Pengujian hipotesis secara parsial

menunjukkan bahwa kualitas jasa dan pelayanan prima berpengaruh terhadap variabel kepuasan konsumen. Itu dapat dilihat dari nilai thitung pada variabel kualitas jasa dan pelayanan prima lebih besar daripada ttabel. Variabel yang mempunyai pengaruh lebih dominan terhadap kepuasan konsumen adalah variabel pelayanan prima karena nilai koefisien regresinya lebih besar daripada variabel kualitas jasa.

Berdasarkan hasil analisis di atas, diketahui bahwa Fhitung > Ftabel $(44,565>3,012)$ yang menunjukkan bahwa hipotesis diterima. Artinya, variabel

kualitas jasa dan pelayanan prima berpengaruh signifikan positif secara bersama-sama terhadap variabel kepuasan konsumen.

Dari nilai koefisien determinasi (R Square) diketahui bahwa kepuasan konsumen dipengaruhi secara bersama-sama oleh variabel kualitas jasa, emarketing dan pelayanan prima sebesar 0,543 atau $54,3 \%$ sedangkan sisanya sebesar $45,7 \%$ dipengaruhi oleh faktor-faktor lain di luar penelitian ini.

\section{KESIMPULAN DAN SARAN}

\subsection{Kesimpulan}

Berdasarkan hasil analisis dan pembahasan yang telah diuraikan sebelumnya, maka dapat ditarik beberapa kesimpulan dari keseluruhan hasil penelitian yaitu sebagai berikut :

1. Variabel kualitas jasa dan pelayanan prima berpengaruh secara simultan terhadap kepuasan konsumen.

2. Variabel pelayanan prima merupakan variabel yang paling dominan mempengaruhi kepuasan konsumen.

\section{DAFTAR PUSTAKA}

Barata, Atep Adya. 2003. Dasar- Dasar Pelayanan Prima. Jakarta : Elex Media Kompetindo.

Ghozali, Imam. 2013. Aplikasi Analisis Multivariat dengan Program SPSS 19. Cetakan Kelima. Semarang: Badan Penerbit Universitas Diponegoro. Irawan, Handi. 2008. 10 Prinsip Kepuasan Pelanggan. Jakarta: PT Elek Media Komputindo. 
Kotler, Philip. 2002. Manajemen Pemasaran. Edisi Milenium. Jilid Pertama. Jakarta. Penerbit: PT Prehalindo 2009. Manajemen Pemasaran, Edisi 13. Jakarta: Erlangga.

Maddy, Khairul. 2009, Hakikat dan Pengertian Pelayanan Prima, Jakarta ; Chama Digit.

Pratomo \& Shaff, Akhsin. 2000. Pelayanan Prima.Bandung: Angkasa Bandung. Tjiptono, Fandy. 2008. Strategi Pemasaran, Edisi-III. Yogyakarta: Andi.

Yamit, Zulian. 2010. Manajemen Kualitas Produk \& Jasa. Yogyakarta. Ekonesia. 